\title{
Potato Cultivars from the Mexican National Program: Sources and Durability of Resistance Against Late Blight
}

\author{
Niklaus J. Grünwald, Mateo A. Cadena Hinojosa, Oswaldo Rubio Covarrubias, \\ Antonio Rivera Peña, John S. Niederhauser, and William E. Fry
}

First and sixth authors: Department of Plant Pathology, Cornell University, 334 Plant Science Building, Ithaca, NY 14853; second, third, and fourth authors: Instituto Nacional de Investigaciones Forestales, Agrícolas y Pecuarias (INIFAP), Conjunto Sedagro, Metepec, Edo. de México 52142, México; and fifth author: 2474 Camino Valle Verde, Tucson, AZ.

Current address of N. J. Grünwald: USDA-ARS, 24106 N. Bunn Road, Prosser, WA 99350.

Accepted for publication 11 March 2002.

\begin{abstract}
Grünwald, N. J., Cadena Hinojosa, M. A., Rubio Covarrubias, O., Rivera Peña, A., Niederhauser, J. S., and Fry, W. E. 2002. Potato cultivars from the Mexican national program: Sources and durability of resistance against late blight. Phytopathology 92:688-693.

The Mexican National Potato Program has produced several cultivars with high levels of field resistance. We evaluated the durability of resistance to potato late blight of a selection of 12 such cultivars using data from 1960 to the present. Data were extracted from the field notebooks

leased between 1965 to 1999 were durable. At least two of the cultivars, namely 'Sangema' and 'Tollocan', have been grown on at least 4 to $5 \%$ of the potato acreage and over long periods of time without decay in levels of field resistance. Pedigrees of the 12 cultivars indicate that most of the field resistance was introgressed from Solanum demissum. Field resistance might also be derived from commonly grown land-race cultivars such as 'Amarilla de Puebla' and 'Leona'. These have been grown in Mexico since about the $1780 \mathrm{~s}$. They have the appearance of $S$. andigenaderived material but their genetic background is unknown.
\end{abstract} located in the archives of the Mexican National Potato Program in the John S. Niederhauser Library in Toluca, Mexico. There was a trend indicating that field resistances to potato late blight of Mexican cultivars re-
Additional keywords: breeding, germ plasm, Phytophthora infestans, S. tuberosum.
The development of cultivars that have durable resistance to pathogens has been a long-standing concern of plant breeders and plant pathologists. Unfortunately, a working definition of durability of resistance of a host to a pathogen has been difficult to achieve. Durable resistance has been defined as resistance that remains effective during its prolonged and widespread use in an environment favorable to the disease (28). Given this definition, durable resistance can only be identified if a cultivar has been grown for a long period of time over a large area in the presence of the pathogen in environments conducive to disease development where resistance did not break down. One difficulty in applying this definition is in determining how long and over what area a cultivar needs to be grown (30). Turkensteen (52) considers potato cultivars that have grown for 10 or more years, that do not show a decrease in the level of resistance, exhibit durable resistance. Another difficulty concerns our ability to quantify durability, because resistance can be based on different mechanisms in the host.

Although many terms have been coined to describe the nature of resistance of potato cultivars to the late blight disease, there are two basic qualities that are distinguishable: (i) resistance based on a gene-for-gene interaction (2), and (ii) resistance that manifests itself by a reduction in the apparent infection rate, herein referred

Corresponding author: N. J. Grünwald

E-mail address: ngrunwald@pars.ars.usda.gov

* The $e$-Xtra logo stands for "electronic extra" and indicates the HTML article available online contains supplemental material not included in the print edition. Pedigrees of the 12 cultivars from the Mexican National Potato Program showing high levels of field resistance are available online.

Publication no. P-2002-0513-010

This article is in the public domain and not copyrightable. It may be freely reprinted with customary crediting of the source. The American Phytopathological Society, 2002. to as rate-reducing resistance and not (yet) determined to be based on a gene-for-gene interaction $(1,33)$. Eleven R-genes have been described in potatoes for resistance to late blight, all of which were found in either Solanum demissum or S. stoloniferum. Resistance based on these 11 single major R-genes (gene-for-gene resistance) in potato cultivars has been overcome rather quickly and has not provided durable resistance $(15,35,52)$. More recently, at least one new major gene for resistance to late blight has been identified from $S$. berthaultii (6) and perhaps another single gene from $S$. bulbocastanum (32). Neither of these genes has been deployed and neither has been overcome. We have, however, found isolates of Phytophthora infestans in central Mexico that have a corresponding avirulence gene overcoming the $S$. berthaultii Rgene (N. J. Grünwald and W. E. Fry, unpublished data), putting in question the durability of this R-gene once it is released.

Soon after it became clear that gene-for-gene resistance based on single major R-genes was not durable, some potato breeders concentrated on developing cultivars with rate-reducing resistance $(48,54)$. This resistance is often measured as resulting in fewer infections per unit of time (lower infection efficiency), decreased sporulation, and a reduction in lesion size $(25,35,50)$. The importance of individual resistance components for overall rate-reducing resistance varies depending on the source of resistance (5). Rate-reducing resistance is expected to be based on many genes (55) or in combination with single genes (quantitative trait loci) conferring quantitative resistance $(6,16)$. It has also been referred to as horizontal, polygenic, race-nonspecific, minor gene, and partial resistance $(33,48)$. Many factors conferring resistance to late blight have been found and mapped on almost every potato chromosome (16), confirming that several genes are responsible for rate-reducing resistance. To further complicate matters, resistance conferred by the R-genes R2, R4, R10, and R11 has been described as partial in nature and is thus easily confused with rate- 
reducing resistance (52) if care is not taken to use differential isolates of $P$. infestans. In this study, we interpret rate-reducing resistance as resistance that can be measured in the field that results in a lower final disease severity and a lower area under the disease progress curve and shows a lower apparent rate of infection than susceptible cultivars.

Potato late blight is currently managed with a variety of tactics, but in commercial agriculture fungicides predominate $(12,27)$. In the Toluca Valley, the presumed center of origin of the late blight pathogen, growers apply anywhere from 16 to 24 applications per growing season (June to September) (21). In many areas of the world, the number of fungicide applications has increased because potato late blight has become more severe $(12,27)$. This development is of particular concern for developing countries. The most appropriate alternative to increasing the intensity of fungicide usage is the use of potato cultivars with high levels of field resistance to late blight. Along with this demand for resistant cultivars comes the concern for how durable this resistance is $(28,35,54)$.

The Mexican National Potato Program originated from activities initiated in 1949 by the Rockefeller Foundation $(37,38,49)$. Today this program forms part of the National Institute of Agricultural, Forestry and Livestock Research (INIFAP) of the Mexican Ministry of Agriculture. It has largely focused on introducing ratereducing resistance into potato cultivars that originated from wild species of Solanum occurring in the central highlands of Mexico.

The Mexican National Potato Program has produced several cultivars with high levels of field resistance $(7,8,20,21)$. Cultivars like Norteña and Rosita express levels of field resistance that are considerably higher than those reported in North American cultivars. In the Toluca Valley of Mexico, where late blight is endemic and severe, these cultivars can be grown without fungicide and still produce yields ranging from 20 to $30 \mathrm{t} / \mathrm{ha}(7,8,21)$. In central Mexico, growers use 16 to 24 fungicide applications with susceptible cultivars, such as Alpha or Atlantic, which comprise at least $50 \%$ of the potato acreage (21). Integration of host resistance and forecasting could considerably reduce the current production costs $(11,14)$.

The Toluca Valley has been described as a center of genetic diversity for both the late blight pathogen and for germ plasm of tuber-bearing Solanum spp. $(13,17,19,22)$. Several Solanum spp. are endemic to the Toluca Valley, including $S$. demissum, by far the most abundant species, followed by $S$. verrucosum, $S$. iopetalum, S. brachycarpum, and S. stoloniferum (46). All of these species can be infected by $P$. infestans (44). Given the close coexistence of $P$. infestans and several wild Solanum spp., we assume that R-genes in the wild germ plasm coevolved with avirulence genes in the late blight pathogen. Given the diversity in this pathogen population, as a consequence of its interaction with the diverse host germ plasm, exposure of cultivars in Mexico to this population of $P$. infestans is one of the most rigorous tests of durability. If resistance is durable in this location, it seems likely that durable resistance could be achievable in other locations worldwide.

Our objectives were to determine if cultivars grown in the Toluca Valley and exposed to a diverse and sexual population of $P$. infestans might have durable resistance. Our approach was to evaluate the resistance of 12 cultivars to potato late blight from 1960 to the present. We used data extracted from field notebooks in the archives of the Mexican National Potato Program in Toluca. We also assembled information on the genetic background of these cultivars.

\section{MATERIALS AND METHODS}

Extraction of data from archival field notebooks. Field data came from notebooks stored at the John S. Niederhauser library of INIFAP in Metepec, Mexico. These notebooks cover 38 years from 1960 to 1998. A database of 6,784 records was assembled and prepared for statistical analysis. Each record contains, as a minimum, the date at which a score for late blight severity was recorded and the corresponding late blight reading on cv. Alpha. Twelve cultivars were selected for analysis. These appear under different names, synonyms, and codes in the database and are shown in Table 1. Additional information on these 12 cultivars currently available in public databases is presented in Table 1.

Most of the records used in this study came from experiments to evaluate germ plasm for resistance to potato late blight. Each year, many clones were evaluated, and the clones we selected were included in most years. To enable comparison over years, the disease severity rating was obtained at the date when susceptible cv. Alpha was just severely defoliated (97 to 100\%). This constraint assured that the reading was taken late in the season, but not at a time long after cv. Alpha had been defoliated. For cvs. Alpha, Sangema (=Rosita), Norteña, Monserrat, and Michoacán, we also included data from field trials conducted in 1998 and $1999(18,20,21)$.

In some years, several trials were conducted and observations from these independent trials were treated as replications. A few years had properly replicated randomized complete block trials, in which case, we include individual observations to derive means and standard deviations.

Between 1960 and 1975, data on disease severity were recorded on a 0 -to- 5 scale $(0=$ no lesions, $1=$ few lesions, $2=$ slightly blighted, $3=$ moderately blighted, $4=$ severely blighted, and $5=$ dead).

TABLE 1. Identifying characteristics of cultivars included in this report

\begin{tabular}{|c|c|c|c|c|c|c|c|}
\hline Cultivar & Synonym $^{\mathrm{a}}$ & CIP number ${ }^{b}$ & $\begin{array}{c}\text { Level of late } \\
\text { blight resistance }\end{array}$ & $\begin{array}{l}\text { R genes } \\
\text { present }^{d}\end{array}$ & $\begin{array}{l}\text { Year of } \\
\text { release }\end{array}$ & $\begin{array}{l}\text { Days to } \\
\text { maturity }\end{array}$ & $\begin{array}{c}\% \text { Potato } \\
\text { acreage planted }^{\mathrm{e}}\end{array}$ \\
\hline Alpha & - & 800050 & $\mathrm{~S}$ & - & 1925 & 90 & 45 \\
\hline Atzimba & 57-DZ-29 & 720045 & MR & + & 1971 & 100 & 0 \\
\hline Ireri & 750489 & - & - & $?$ & 1990 & 90 & 0.1 \\
\hline Juanita & $58-E S-37$ & 720046 & - & $?$ & 1971 & 90 & 0 \\
\hline Mexiquense & CEX-69-1, ICTA-77, 4-NX-97 & 720057 & MR & + & 1988 & 105 & 0.2 \\
\hline Michoacán & 65-BK-269, AJU-69-1 & 573272 & $\mathrm{R}$ & + & 1988 & 90 & 0.2 \\
\hline Monserrat & CEW-69-1, 63-JP-13 & 575049 & $\mathrm{R}$ & + & 1988 & 100 & 0.5 \\
\hline Montsama & 61-DN-11, ACD-69-1 & 720049 & $\mathrm{R}$ & - & 1971 & 90 & 0 \\
\hline Murca & 720097, 63-HV-30 & 676006 & - & $?$ & 1970 & 90 & 0 \\
\hline Norteña & 69-107-B, 750815 & - & - & $?$ & 1992 & 105 & 1.5 \\
\hline Puebla & 750851 & - & - & $?$ & 1984 & 95 & 0.1 \\
\hline Sangema & Rosita, 61-EA-5, AJS-69-1 & 720044 & MR & + & 1971 & 105 & 4 \\
\hline Tollocan & CCU-69-1, 65-ZS-4 & 720054 & $\mathrm{R}$ & + & 1980 & 90 & 5 \\
\hline
\end{tabular}

a The synonyms presented are alternate codes for the same clone used in the field notebooks.

${ }^{\mathrm{b}}$ CIP code refers to the identification given to the respective cultivar by the International Potato Center (CIP), Lima, Peru.

${ }^{c}$ Data was extracted from the CIP database: $\mathrm{R}=$ resistant; $\mathrm{MR}=$ moderately resistant; $\mathrm{S}=$ susceptible; and $-=$ information not available.

${ }^{\mathrm{d}}$ Data was extracted from the CIP database: $+=\mathrm{R}$ genes present; $-=\mathrm{R}$ genes absent; and $?=$ information not available.

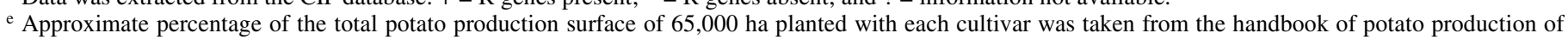
INIFAP (47). 
This scale was transformed to percent disease severity in the following way: $0=0 \%, 1-=10 \%, 1=20 \%, 1+=30 \%, 2=40 \%$, $2+=50 \%, 3=60 \%, 3+=70 \%, 4=80 \%, 4+=90 \%$, and $5=$ $100 \%$. After 1975, a 1-to-9 scale was used and was transformed as published by Henfling (23). Introduction of the 1-to-9 scale made it possible to select readings in which cv. Alpha was scored at $97.5 \%$ disease severity.

Statistical analysis. Regression analysis of disease severity (y) against year was conducted for disease severity values selected when cv. Alpha was just below 100\% (1960 to 1975) or near 97.5\% (1976 to 1999). A slope of a linear regression of $y$ versus year was calculated and a positive slope that significantly deviated from 0 was taken as a trend that the rate-reducing resistance of the cultivar was not durable. Data were recorded in a spreadsheet and all subsequent statistical analyses were conducted using the Statistical Analysis System (SAS Institute, Cary, NC).

\section{RESULTS}

The Mexican cultivars exhibited high levels of field resistance (Fig. 1). Mean disease severity of the Mexican cultivars ranged between 3 and $37 \%$. Some cultivars had larger standard deviations for disease severity from year to year or within 1 year (Fig. 1; Table 2). 'Montsama', in particular, showed a standard deviation of 32 across all years and a range of mean disease severity from year to year between 7.5 and $85 \%$.

Cultivars that were resistant in 1 year appeared resistant in all years. There was no trend to indicate that field resistance of Mexican cultivars to potato late blight from 1965 to 1999 was not durable (Fig. 1; Table 2). Lack of a significant slope or a negative slope would indicate durable resistance; a positive slope would indicate nondurable resistance. Most regressions of disease severity versus time showed a negative slope (Fig. 1; Table 2). Except for cvs. Juanita and Rosita, which showed a significantly negative slope, regressions did not result in significant slopes or coefficients of determination (Table 2).

Pedigrees of the 12 cultivars show some interesting relationships. Most of the field resistance seemed to be derived from $S$. demissum. Field resistance might also be derived from land-race cultivars locally known as 'Criollas', namely 'Amarilla de Puebla' and 'Leona'. The cvs. Puebla and Norteña share cv. Atzimba as parent. Clones starting with "AC," such as AC-25953, came from

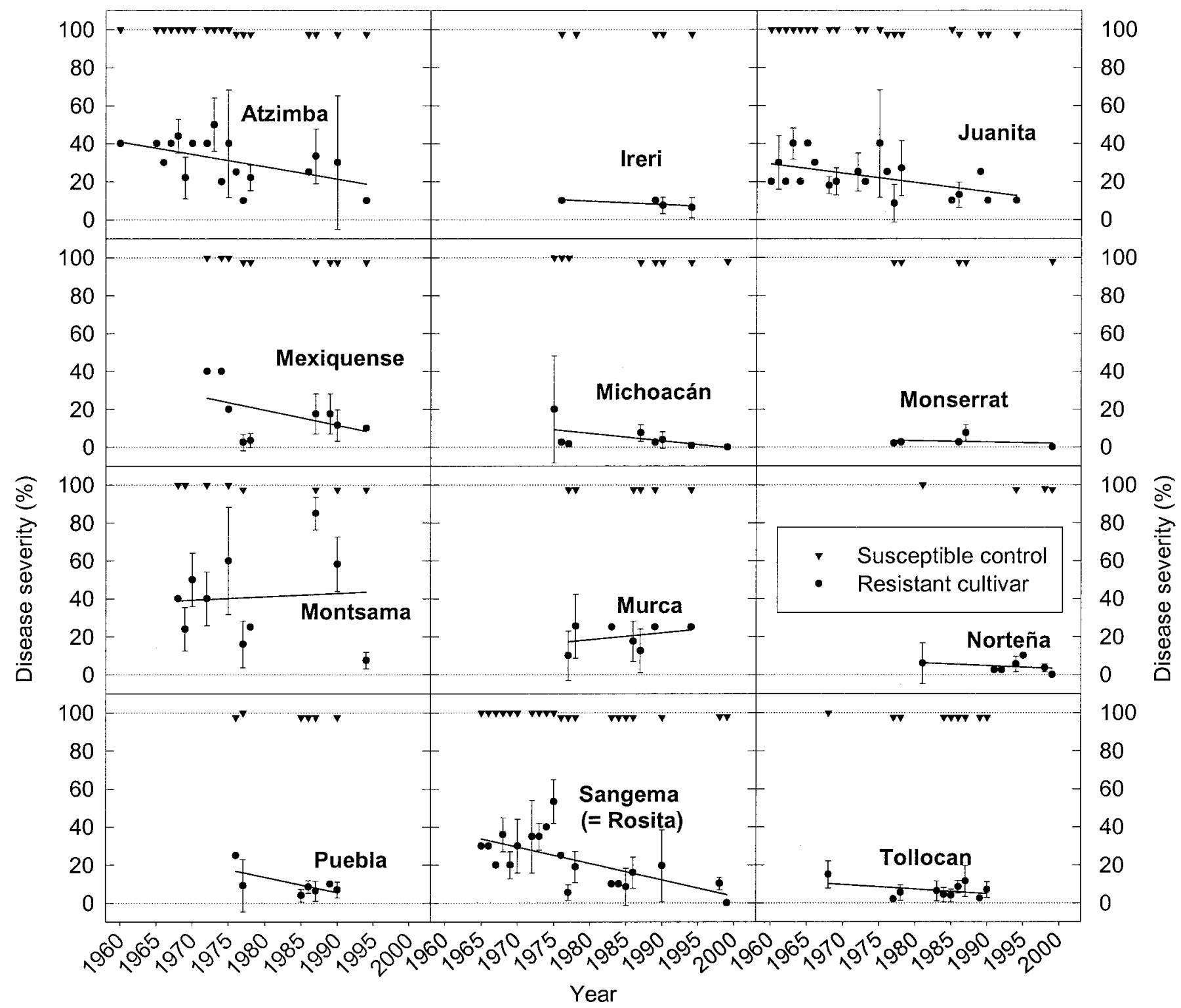

Fig. 1. Disease severity (percent) of 12 cultivars from the Mexican National Potato Program (INIFAP) that show high levels of field resistance. Shown are means \pm standard deviations when cv. Alpha was just at 100\% (1960 to 1975) or 97.5\% (1976 to 1999). 
W. Rudorf in Germany. The clone AC-25953, appearing in the pedigree of 9 of the 12 cultivars, is a hybrid produced by $S$. demissum, S. tuberosum, and S. andigena (42). Clones starting with "US" were named by J. S. Niederhauser's program, for example US-133-3 (clone 3 of breeding population 133), but the clones came from F. J. Stevenson (USDA, Beltsville, MD) and had a corresponding USDA number starting with " $\mathrm{B}$ " for Beltsville such as B-3716. Clone B-2131-3 is a USDA selection derived from crossing $S$. demissum and $S$. tuberosum (42). The breeding clone US-135-7 (=cv. Anita) is the result of a self of a clone derived from AC-25953 and USDA B-2131-3 (42). The breeding clone B$355-24$ is most likely a self of B-355 (=US-355) in which clone 24 was selected. 'Alpha' and 'Loman' and the clone Hol-32 came from the Netherlands. Clone 58-ES-37 (Loman $\times$ US-135-7; also referred to as 720046), shown in the pedigree of cv. Tollocan, is cv. Juanita. Clone 65-IND-217-25 also appears with the numbers CIP-573265, AEX-69-1, and CFM-69-1 in notebooks. Clones labeled with "IND" were sent from W. Black's germ plasm collection in India, and derived their resistance from S. demissum.

\section{DISCUSSION}

Twelve Mexican cultivars, grown between 1960 and 1999, and exhibiting high degrees of rate-reducing resistance, did not loose resistance over time, indicating that this resistance is durable. Durable resistance was defined by Johnson (28) as resistance that remains effective in a cultivar that is widely grown for a long period of time in an environment favorable to the disease. The 12 cultivars were grown in an environment favorable to the pathogen and in the presence of virulent pathogen genotypes. 'Sangema' and 'Tollocan' have been widely grown in Mexico and were grown on approximately 4 and $5 \%$ of the potato acreage in 2001 (INIFAP, unpublished data) (Table 1) and 1 and $6 \%$ before 2000, respectively. Thus, Johnson's requirements for the evaluation of durability were satisfied for at least some of the cultivars reported herein.

Our results are in agreement with previous studies on durability of rate-reducing resistance in potato cultivars. van der Plank (54) reported that 10 cultivars used in the Netherlands from 1938 to 1968 maintained their relative ranking, concluding that resistance is stable. Similarly, Turkensteen (52) reported that the ranking of Dutch cultivars for foliar blight did not change, except for those cultivars carrying R-genes that were overcome in the first 5 to 10 years. Over a period of 17 years, Thurston (48) and Thurston et al. (50) saw no decline in rate-reducing resistance of several clones. Our observations are also consistent with earlier evaluations, in which over a period of 6 or 10 years, multigenic resistance was maintained at the original level in each clone grown $(35,36)$. Moreover, for a period of 21 years (1951 to 1972), in the so-called "germ plasm bank trial," over 1,800 (unspecified) clones were planted annually in order of resistance (37). Less than $5 \%$ of the selections $(>1,800$ clones) had to be reclassified after the first 2 years of exposure in the field. From these observations, Niederhauser concluded that horizontal resistance was both durable (did not decay over time) and stable (ranking of resistance between clones did not change significantly) (37). Work by Inglis et al. (24) indicated that there was little or no change in rank of a cultivar's resistance in response to different populations of $P$. infestans.

Decay in the level of rate-reducing resistance might be expected if the pathogen is able to adapt to cultivars with rate-reducing resistance. Although some studies indicate that $P$. infestans is unlikely to adapt to cultivars with rate-reducing resistance $(25,43)$, others report evidence for adaptation $(3,26,29)$. In two of the studies reporting adaptation, the work was conducted in vitro on tuber slices $(3,26)$.

Several aspects of the population structure of $P$. infestans and the chronology of epidemic development in the Toluca Valley have changed very little. In the Toluca Valley, late blight often appears between the last week of June and the second week of July. Very recently, we observed first lesions on 3 July 1997, 16 July 1998, 14 July 1999, and 25 June 2000 (N. J. Grünwald, unpublished data) (21). Apparently, first outbreaks of blight still occur around the same date as in the 1950s when first symptoms appeared on 29 June 1953 (34), 10 July 1954 (41), and 5 July 1955 (39). Similarly, genetic diversity for virulence was high in the 1950s $(31,40)$ and in 1985-86 (45). Genetic diversity in the central highlands of Mexico, based on mating-type frequencies, allozyme, and restriction fragment length polymorphic fingerprint diversity, is high, and it is assumed that these highlands are the center of origin of the late blight pathogen $(13,17,19,51)$. All these facts indicate a rather stable Solanum- $P$. infestans host-pathosystem in the Toluca Valley and lend further support to the value of the data extracted from the archives.

Researchers from the Mexican Rockefeller Foundation Program and the Mexican National Potato Program developed these 12 cultivars (38). Most of the cultivars studied in this report have several major R-genes (Table 1). Despite the presence of R-genes, there was no "Vertifolia effect" sensu van der Plank (53) detected in the Mexican program. (The Vertifolia effect is the masking of background susceptibility by effective R-genes.) This highlights the tremendous value of the Toluca valley for late blight breeders and pathologists.

Cultivars with very high levels of field resistance are available $(7,8,18,21)$, and previous work has shown that high levels of field resistance can be combined with fungicide applications at lower rates or at a lower frequency without loss of disease suppression $(4,9,10,21)$. We would thus expect that cultivars exhibiting high rates of rate-reducing resistance could contribute to a significant reduction in the number of fungicide applications. This report, and

TABLE 2. Analysis of the behavior of 12 cultivars from the Mexican National Potato Program over years ${ }^{\mathrm{a}}$

\begin{tabular}{|c|c|c|c|c|c|}
\hline Cultivar & Mean \pm SD of disease severity $(\%)$ & Regression equation & $R^{2}$ & $P>F$ regression and slope & $P>F$ intercept \\
\hline Atzimba & $24 \pm 19$ & $y=1,077-0.53 \times Y E A R$ & 0.080 & 0.0669 & 0.0596 \\
\hline Ireri & $7 \pm 4$ & $y=-179+0.09 \times Y E A R$ & 0.020 & 0.7303 & 0.7398 \\
\hline Juanita & $15 \pm 11$ & $y=1,180-0.59 \times Y E A R$ & 0.225 & 0.0001 & 0.0001 \\
\hline Mexiquense & $9 \pm 8$ & $y=149-0.07 \times Y E A R$ & 0.002 & 0.8460 & 0.8333 \\
\hline Michoacán & $3 \pm 4$ & $y=780-0.39 \times Y E A R$ & 0.142 & 0.0842 & 0.0826 \\
\hline Monserrat & $3 \pm 3$ & $y=132-0.07 \times Y E A R$ & 0.040 & 0.4260 & 0.4168 \\
\hline Montsama & $37 \pm 32$ & $y=-720+0.38 \times Y E A R$ & 0.018 & 0.4851 & 0.5071 \\
\hline Murca & $19 \pm 12$ & $y=-285+0.15 \times Y E A R$ & 0.005 & 0.7613 & 0.0950 \\
\hline Norteña & $5 \pm 6$ & $y=393-0.20 \times Y E A R$ & 0.065 & 0.2931 & 0.2877 \\
\hline Puebla & $8 \pm 7$ & $y=948-0.47 \times Y E A R$ & 0.100 & 0.1513 & 0.1481 \\
\hline Rosita & $12 \pm 11$ & $y=1,956-0.98 \times Y E A R$ & 0.299 & 0.0001 & 0.0001 \\
\hline Tollocan & $6 \pm 5$ & $y=671-0.34 \times Y E A R$ & 0.064 & 0.1118 & 0.1078 \\
\hline
\end{tabular}

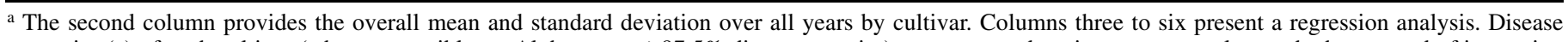
severity $(y)$ of each cultivar (when susceptible cv. Alpha was at $\geq 97.5 \%$ disease severity) was regressed against year to evaluate whether a trend of increasing disease severity could reflect a breakdown in resistance. 
previous work, indicates that rate-reducing resistance detected in the Toluca Valley is durable. We thus see tremendous potential in the use of these Mexican cultivars, and others with similar resistance, for development of more sustainable potato farming practices, particularly for developing countries.

\section{ACKNOWLEDGMENTS}

This work was funded by the CEEM (Cornell-Eastern Europe-Mexico) Potato Late Blight Project, Cornell University, and by USDA-CRIS project 5354-21220-009-00. Data collection for this research was made possible by permission of the Instituto Nacional de Investigaciones Forestales, Agrícolas y Pecuarias (INIFAP). Most of the original data was gathered by many researchers from the Oficina de Estudios Especiales (Rockefeller Foundation), Instituto Nacional de Investigación Agrícola (INIA), and INIFAP: J. Cervantes Ramo, S. Delgado Sánchez, J. Fernández Elguezabal, F. Flores Gutiérrez, V. Magallanes González, H. Montelongo, G. Pérez Ugalde, A. Rivera-Peña, and M. Villareal González. We thank PICTIPAPA (Programa Internacional Cooperativo del Tizón Tardío de la Papa, A.C.) and H. Lozoya-Saldaña for their support; C. A. Reyes for extracting the data from the field notebooks; and C. R. Brown, J. P. Helgeson, and D. Corsini for comments on an earlier version of the manuscript.

\section{LITERATURE CITED}

1. Black, W. 1970. The nature and inheritance of field resistance to late blight (Phytophthora infestans) in potatoes. Am. Potato J. 47:279-288.

2. Black, W., Masterbroek, C., Mills, W. R., and Peterson, L. C. 1953. A proposal for an international nomenclature of races of Phytophthora infestans and of genes controlling immunity in Solanum demissum derivatives. Euphytica 2:173-179.

3. Caten, C. E. 1974. Intra-racial variation in Phytophthora infestans and adaptation to field resistance for potato late blight. Ann. Appl. Biol. 77:259-270.

4. Clayton, R. C., and Shattock, R. C. 1995. Reduced fungicide inputs to control Phytophthora infestans in potato cultivars with high levels of polygenic resistance. Potato Res. 38:399-405.

5. Colon, L. T., Budding, D. J., Keizer, L. C. P., and Pieters, M. J. J. 1995. Components of resistance to late blight (Phytophthora infestans) in eight South American Solanum species. Eur. J. Plant Pathol. 101:441-456.

6. Ewing, E. E., Šimko, I., Smart, C. D., Bonierbale, M. W., Mizubuti, E. G. S., May, G. D., and Fry, W. E. 2000. Genetic mapping from field tests of qualitative and quantitative resistance to Phytophthora infestans in a population derived from Solanum tuberosum and Solanum berthaultii. Mol. Breed. 6:25-36.

7. Flores-Gutiérrez, F. X. 1997. Resistencia de campo al tizón tardío Phytophthora infestans (Mont.) de Bary en variedades y clones de papa Méxicanos. Agric. Téc. Méx. 23:15-25.

8. Flores-Gutiérrez, F. X., and Cadena-Hinojosa, M. A. 1996. Evaluation of horizontal resistance and effects of R-genes in ten Mexican cultivars against potato late blight (Phytophthora infestans) under natural conditions in the central plateau of Mexico. Rev. Mex. Fitopatol. 102:97102.

9. Fry, W. E. 1975. Integrated effects of polygenic resistance and a protective fungicide on development of potato late blight. Phytopathology 65:908-911.

10. Fry, W. E. 1978. Quantification of general resistance of potato cultivars and fungicide effects for integrated control of potato late blight. Phytopathology 68:1650-1655.

11. Fry, W. E. 1980. Integration of host resistance and pesticides to manage disease. Prot. Ecol. 2:259-264.

12. Fry, W. E., and Goodwin, S. B. 1997. Resurgence of the Irish potato famine fungus. BioScience 47:363-371.

13. Fry, W. E., Goodwin, S. B., Dyer, A. T., Matuszak, J. M., Drenth, A., Tooley, P. W., Sujkowski, L. S., Koh, Y. J., Cohen, B. A., Spielman, L. J., Deahl, K. L., Inglis, D. A., and Sandlan, K. P. 1993. Historical and recent migrations of Phytophthora infestans: Chronology, pathways, and implications. Plant Dis. 77:653-661.

14. Fry, W. E., and Shtienberg, D. 1990. Integration of host resistance and fungicide to manage potato diseases. Can. J. Plant Pathol. 12:111-116.

15. Gallegly, M. E. 1968. Genetics of pathogenicity of Phytophthora infestans. Annu. Rev. Phytopathol. 6:375-396.

16. Gebhardt, C., and Valkonen, J. P. T. 2001. Organization of genes controlling disease resistance in the potato genome. Annu. Rev. Phytopathol. 39:79-102.

17. Goodwin, S. B., Spielman, L. J., Matuszak, J. M., Bergeron, S. N., and
Fry, W. E. 1992. Clonal diversity and genetic differentiation of Phytophthora infestans populations in northern and central Mexico. Phytopathology 82:955-961.

18. Grünwald, N. J., Cadena, M., Rubio, O., Rivera, A., and Fry, W. E. 1999. Contribution of host-resistance to integrated control of late blight in the Toluca valley. (Abstr.) Phytopathology 89(suppl.):S30.

19. Grünwald, N. J., Flier, W. G., Sturbaum, A. K., Garay-Serrano, E., van den Bosch, T. B. M., Smart, C. D., Matuszak, J. M., Lozoya-Saldaña, H., Turkensteen, L. J., and Fry, W. E. 2001. Population structure of Phytopthora infestans in the Toluca valley region of central Mexico. Phytopathology 91:882-890.

20. Grünwald, N. J., and Fry, W. E. 2000. Integration of SimCast and resistant cultivars to manage potato late blight in the Toluca Valley. Pages 96-107 in: Proceedings of the Workshop on the European network for development of an integrated control strategy of potato late blight. $\mathrm{H}$. Schepers, ed. Applied Research for Arable Farming and Field Production of Vegetables, Lelystad, the Netherlands.

21. Grünwald, N. J., Rubio-Covarrubias, O. A., and Fry, W. E. 2000. Potato late blight management in the Toluca Valley: Forecasts and resistant cultivars. Plant Dis. 84:410-416.

22. Hawkes, J. G. 1990. The Potato: Evolution, Biodiversity and Genetic Resources. Smithsonian Institution Press, Washington, D.C.

23. Henfling, J. W. 1987. Late Blight of Potato-Phytophthora infestans. International Potato Center, Lima, Peru.

24. Inglis, D. A., Johnson, D. A., Legard, D. E., Fry, W. E., and Hamm, P. B. 1996. Relative resistances of potato clones in response to new and old populations of Phytophthora infestans. Plant Dis. 80:575-578.

25. James, R. V., and Fry, W. E. 1983. Potential for Phytophthora infestans populations to adapt to potato cultivars with rate-reducing resistance. Phytopathology 73:984-988.

26. Jeffrey, S. I. B., Jinks, J. L., and Grindle, M. 1962. Intraracial variation in Phytophthora infestans and field resistance to potato late blight. Genetica 32:323-338.

27. Johnson, D. A., Cummings, T. F., and Hamm, P. B. 2000. Cost of fungicides used to manage potato late blight in the Columbia Basin: 1996 to 1998. Plant Dis. 84:399-402.

28. Johnson, R. 1984. A critical analysis of durable resistance. Annu. Rev. Phytopathol. 22:309-330.

29. Latin, R. X., MacKenzie, D. R., and Cole, H., Jr. 1981. The influence of host and pathogen genotypes on the apparent infection rates of potato late blight epidemics. Phytopathology 71:82-85.

30. Leach, J. E., Vera Cruz, C. M., Bai, J. F., and Leung, H. 2001. Pathogen fitness penalty as a predictor of durability of disease resistance genes. Annu. Rev. Phytopathol. 39:187-224.

31. Mills, W. R., and Niederhauser, J. S. 1953. Observations of races of Phytophthora infestans in Mexico. Phytopathology 43:454-455.

32. Naess, S. K., Bradeen, J. M., Wielgus, S. M., Haberlach, G. T., McGrath, J. M., and Helgeson, J. P. 2000. Resistance to late blight in Solanum bulbocastanum is mapped to chromosome 8. Theor. Appl. Genet. 101:697704.

33. Nelson, R. R. 1978. Genetics of horizontal resistance to plant diseases. Annu. Rev. Phytopathol. 16:359-378.

34. Niederhauser, J. S. 1954. Report on 1953 Toluca (Mexico) field test for late blight resistance of seedlings sent by Dr. F. J. Stevenson. Pages 241245 in: USDA-ARS, 24th Annu. Rep. Natl. Potato Breed. Prog. Beltsville, MD.

35. Niederhauser, J. S. 1961. Genetic studies of Phytophthora infestans and Solanum species in relation to late-blight resistance in potato. Recent Adv. Bot. 1:491-497.

36. Niederhauser, J. S. 1962. Evaluation of multigenic "field resistance" of the potato to Phytophthora infestans in 10 years of trials at Toluca, Mexico. Phytopathology 52:746.

37. Niederhauser, J. S. 1991. Phytophthora infestans: The Mexican connection. Pages 25-45 in: Phytophthora. J. A. Lucas, R. C. Shattock, D. S. Shaw, and L. R. Cooke, eds. Cambridge University Press, Cambridge.

38. Niederhauser, J. S. 1993. International cooperation in potato research and development. Annu. Rev. Phytopathol. 31:1-21.

39. Niederhauser, J. S., Cervantes, J., and Eide, C. J. 1956. Report on 1955 Toluca (Mexico) field test for late blight resistance of seedlings sent by F. J. Stevenson. Pages 99-102 in: USDA-ARS, 26th Annu. Rep. Natl. Potato Breed. Prog. Beltsville, MD.

40. Niederhauser, J. S., Cervantes, J., and Servin, L. 1954. Late blight in Mexico. Am. Potato J. 31:233-237.

41. Niederhauser, J. S., Cervantes, J., and Servin, L. 1955. Report on 1954 Toluca (Mexico) field test for late blight resistance of seedling sent by Dr. F. J. Stevenson. Pages 95-98 in: USDA-ARS, 25th Annu. Rep. Natl. Potato Breed. Prog. Beltsville, MD.

42. Niederhauser, J. S., Fernandez, J., Cervantes, J., Perez, G., and Delgado, S. 1959. Tres variedades de papa resistentes al tizón tardío. Agric. Téc. Méx. 9:28-30. 
43. Paxman, G. J. 1963. Variation in Phytophthora infestans. Eur. Potato J. 6:14-23.

44. Rivera-Peña, A. 1990. Wild tuber-bearing species of Solanum and incidence of Phytophthora infestans (Mont.) de Bary on the Western slopes of the volcano Nevado de Toluca. 2. Distribution of Phytophthora infestans. Potato Res. 33:341-347.

45. Rivera-Peña, A. 1990. Wild tuber-bearing species of Solanum and incidence of Phytophthora infestans (Mont.) de Bary on the Western slopes of the volcano Nevado de Toluca. 3. Physiological races of Phytophthora infestans. Potato Res. 33:349-355.

46. Rivera-Peña, A., and Molina-Galan, J. 1989. Wild tuber-bearing species of Solanum and incidence of Phytophthora infestans (Mont.) de Bary on the Western slopes of the volcano Nevado de Toluca. 1. Solanum species. Potato Res. 32:181-195.

47. Rubio Covarrubias, O. A., Rivera Peña, A., Rangel González, J. A., Cadena Hinojosa, M., Flores López, R., Rocha Rodríguez, R., Magallanes González, J. V., Ortíz Trejo, C., Díaz Hernandez, C., López Delgado, H., Zavala Quintana, T. E., Díaz Valasis, M., and Paredes Tenorio, A. 2000. Manual para la Producción de Papa en las Sierras y Valles Altos del Centro de México. Inst. Nac. Investig. For. Agríc. Pecuarias, Zinacantepec, Estado de México, México.
48. Thurston, H. D. 1971. Relationship of general resistance: Late blight of potato. Phytopathology 61:620-626.

49. Thurston, H. D. 1980. International potato disease research for developing countries. Plant Dis. 64:252-257.

50. Thurston, H. D., Heidrick, L. E., and Guzman, N. J. 1962. Partial resistance to Phytophthora infestans (Mont.) de Bary within the Coleccion Central Colombiana. Am. Potato J. 39:63-69.

51. Tooley, P. W., Fry, W. E., and Villareal-Gonzalez, M. J. 1985. Isozyme characterization of sexual and asexual Phytophthora infestans populations. J. Hered. 76:431-435.

52. Turkensteen, L. J. 1993. Durable resistance of potatoes against Phytophthora infestans. Pages 115-124 in: Durability of Disease Resistance. T. Jacobs and J. E. Parlevliet, eds. Kluwer Academic Press, Dordrecht, the Netherlands.

53. van der Plank, J. E. 1968. Disease Resistance in Plants. Academic Press, New York.

54. van der Plank, J. E. 1971. Stability of resistance to Phytophthora infestans in cultivars without R genes. Potato Res. 14:263-270.

55. Wastie, R. L. 1991. Breeding for resistance. Pages 193-224 in: Phytophthora infestans, the Cause of Late Blight of Potato. D. S. Ingram and P. H. Williams, eds. Academic Press, London. 